\title{
The Importance of Alternative Drive Vehicles in Road Transport in Poland and the European Union
}

\author{
Damian Frej $^{1^{*}}$, Paweł Grabski ${ }^{1}$ and Emilia Szumska ${ }^{1}$ \\ ${ }^{1}$ Department of Automotive Engineering and Transport, Kielce University of Technology, Kielce, \\ Poland,e-mail:frejdamian@gmail.com,pgrabski@tu.kielce.pl,eszumska@tu.kielce.pl
}

\section{*Corresponding author: Damian Frej}

Received: 14 October 2020; Revised: 3 November 2020; Accepted: 19 February 2021; Published: 28 May 2021

\begin{abstract}
The development of electromobility in Poland and the whole world is an inevitable process. Every year, electric vehicles and vehicles powered by renewable fuels become more and more popular. It should be noted that the development of infrastructure for electric vehicles and the pursued environmental policy with the related subsidies for the purchase of electric vehicles are an important aspect encouraging the purchase of this type of vehicle. The article presents a comparison of the popularity of vehicles powered by renewable energy sources in Poland and other European Union countries, as well as the characteristics of the most common alternative fuels. Its main objective is to specify the importance of passenger cars with alternative drive sources across the selected EU countries.
\end{abstract}

Keywords: Electromobility, alternative drive, alternative fuels

\section{Introduction}

Currently, electric vehicles are becoming increasingly more popular and even more able to compete with vehicles with a conventional combustion engines. Every year, more and more vehicles with an electric engine appear on the market. Moreover, it should be noted that such models constitute a new challenge for passenger car designers, as they are made from scratch as new vehicles exclusively intended for electric drive [1-3].

The pursuit of the international economy to maximize profits, and the global development of technology referred to as the industrial revolution resulted in increased release of large amounts of harmful substances into the atmosphere. One of the main harmful substances/pollutants that need to be reduced in is Carbon dioxide. The works by [4-6] deal with the possibilities of reducing carbon dioxide and other harmful substances from road transport. One of the aspects of reducing the release 
of carbon dioxide into the atmosphere is the reduced consumption of conventional fuels and their replacement with renewable energy sources.

The use of vehicles equipped with electric drive (EV) is consistent with eco-friendly ideas and at the same time contributes to solving many problems related to environmental protection. The works by [7-9] focus on assessing the harmfulness of urban transport in terms of ecology. Road transport is one of the main sources of environmental pollution. The works by [10-12] present the importance of hybrid vehicles in terms of reducing the emission of harmful substances. A hybrid vehicle is a vehicle using a combination of two types of drives, most commonly an electric and internal combustion engine. Such vehicles can use their engines simultaneously or alternately when needed, depending on a specific situation, e.g. using electric drive in towns and a combustion engine outside the town $[13,18,19]$.

The works by [13-15] deal with the positive aspects of electromobility. According to the authors, the greatest advantage of using electric drive is undoubtedly the reduction of exhaust emissions, which contain many harmful chemical compounds. The disadvantages include e.g. operating costs and vehicle charging time.

\section{Passenger Vehicles in the EU}

The newly registered passenger vehicles in the European Union by type of fuel in the last 4 years are presented in the following figure (Fig.1). Alternative fuel passenger vehicles (AFV) showed a notable increase in use in the monitored period. In 2016, AFV accounted for $4 \%$ of all newly registered passenger vehicles, while in 2019, the share was $11 \%$. The number of diesel passenger vehicles decreased gradually within this period. In 2016, passenger vehicles with diesel engine comprised a half of total number of newly registered vehicles. In 2019, this share decreased to $31 \%$.

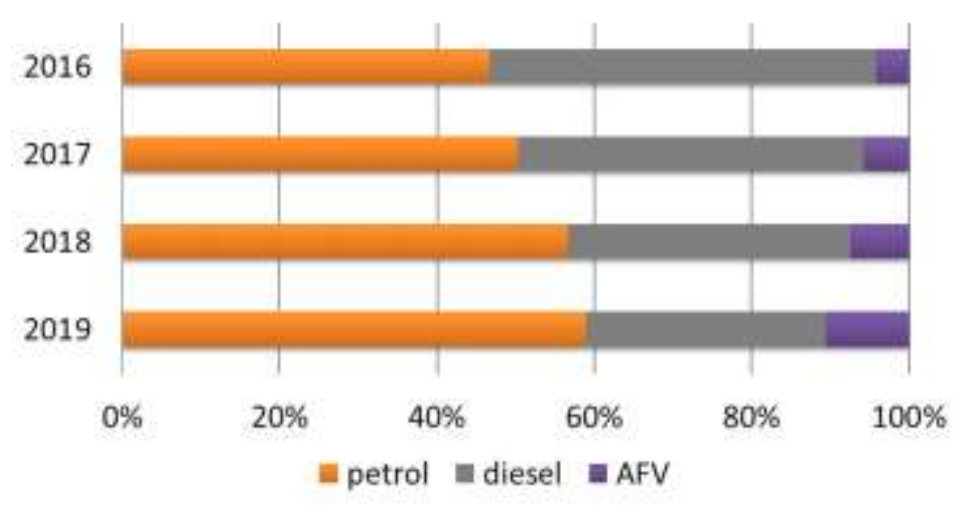

Fig. 1 Newly registered passenger vehicles by type of fuel. Source: [13]

In 2019, the highest number of new alternative fuel passenger vehicles was recorded in Italy (Fig.2). Alternative fuel vehicles account for $11 \%$ of newly registered passenger vehicles. The 
country with the second highest number of new alternative fuel passenger vehicles was Germany, where the share of alternative fuel vehicles in new registrations was only $3.5 \%$. The highest numbers of newly registered alternative fuel passenger vehicles in 2019 were recorded in the Netherlands, France, and Sweden. It is worth noting that in the Netherlands, electric vehicles account for more than $15 \%$ of all newly registered passenger vehicles.

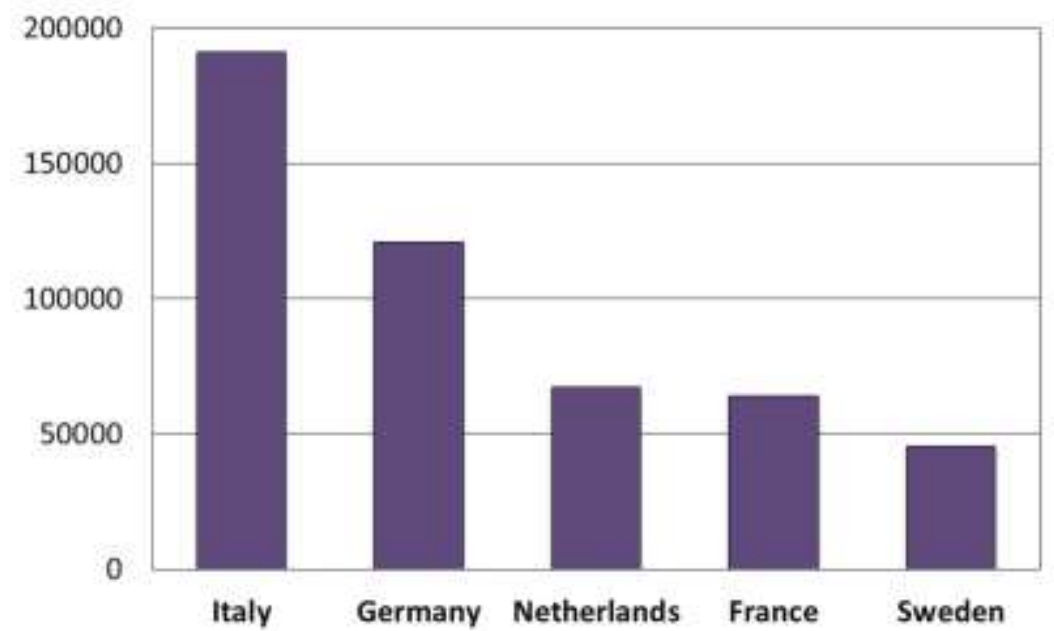

Fig. 2 European countries with the highest number of newly registered alternative fuel passenger vehicles in 2019. Source: [13]

The number of passenger vehicles equipped with electric drive is constantly increasing, reaching the number of 140,422 vehicles in 2019 (Fig.3). Since 2011, there has been an impressive growth in their number, accounting approximately for $95 \%$. In 2019, the highest number of newly registered electric passenger vehicles was recorded in the Netherlands and Germany (Fig.4). The share of electric vehicles in new registrations was $15.2 \%$ and $1.8 \%$ respectively. The EU Member States with the highest number of newly registered electric vehicles include France, Sweden, and Italy.

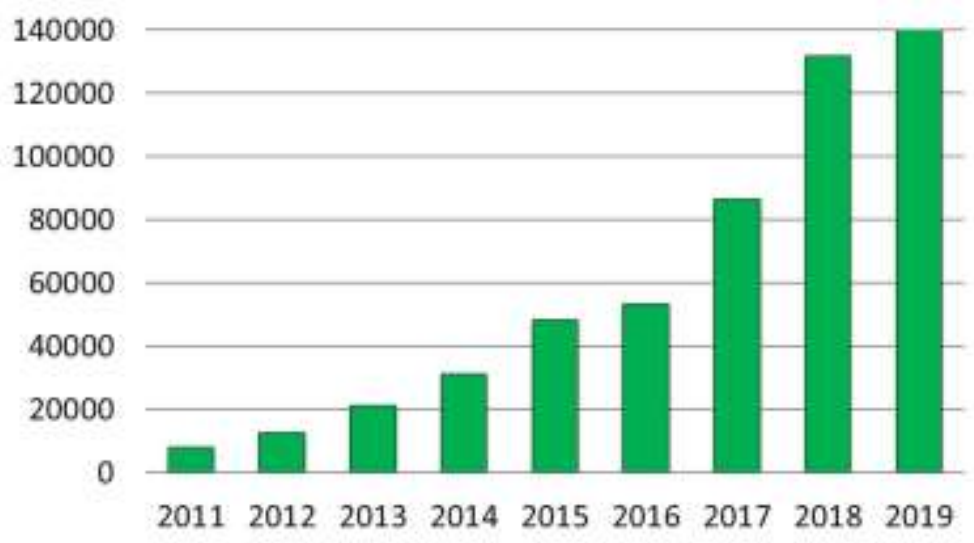

Fig. 3 Newly registered electric passenger vehicles. Source: [14] 


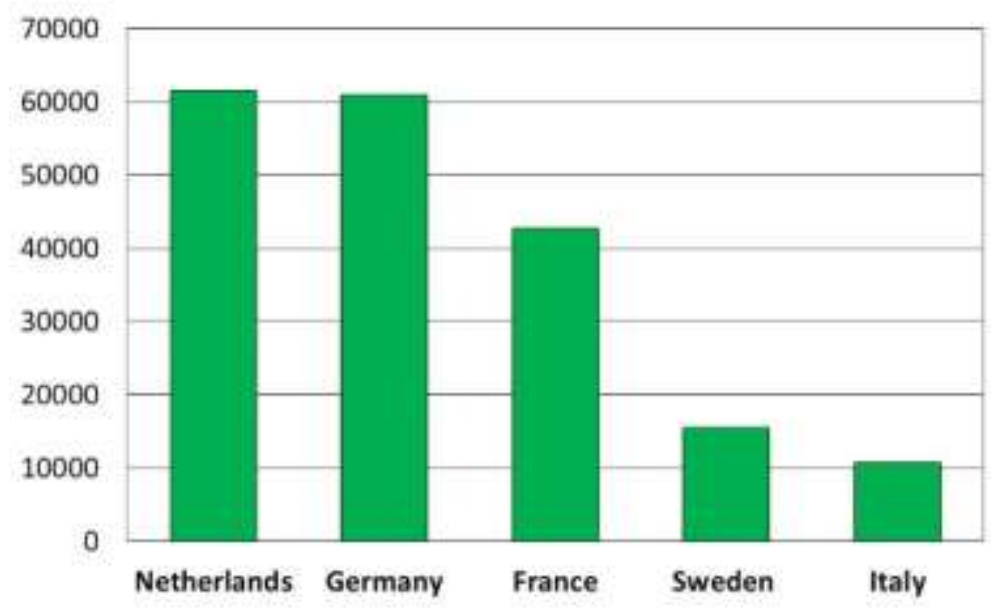

Fig. 4 European countries with the highest number of newly registered electric passenger vehicles in 2019. Source: [14]

The plug-in hybrid passenger vehicles have become highly popular recently. In 2019, the number of newly registered plug-in hybrid passenger vehicles was more than three times greater than in 2018 (see Fig.5). The five EU Member States with the highest number of newly registered plug-in hybrid vehicles in 2019 included Germany, Sweden, France, Belgium, and Spain. It is worth noting that in Sweden, plug-in hybrids account approximately for $8 \%$ of all newly registered passenger vehicles.

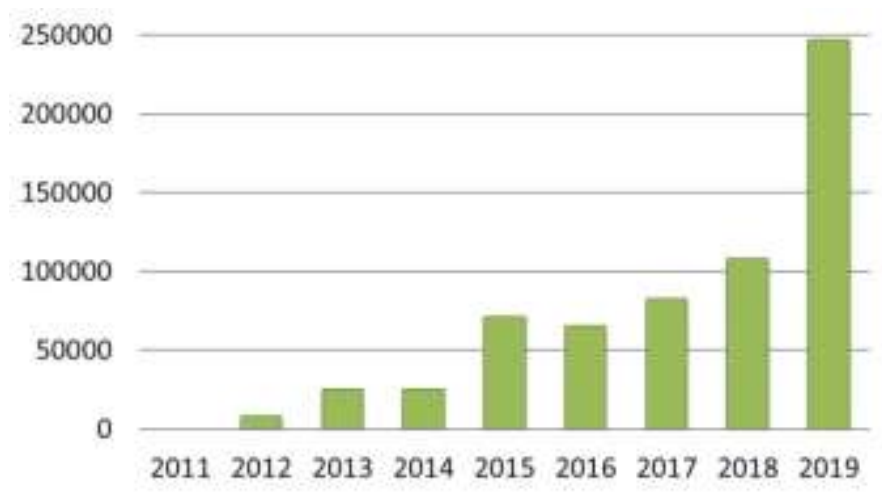

Fig. 5 Newly registered plug-in hybrid passenger vehicles. Source: [14] 


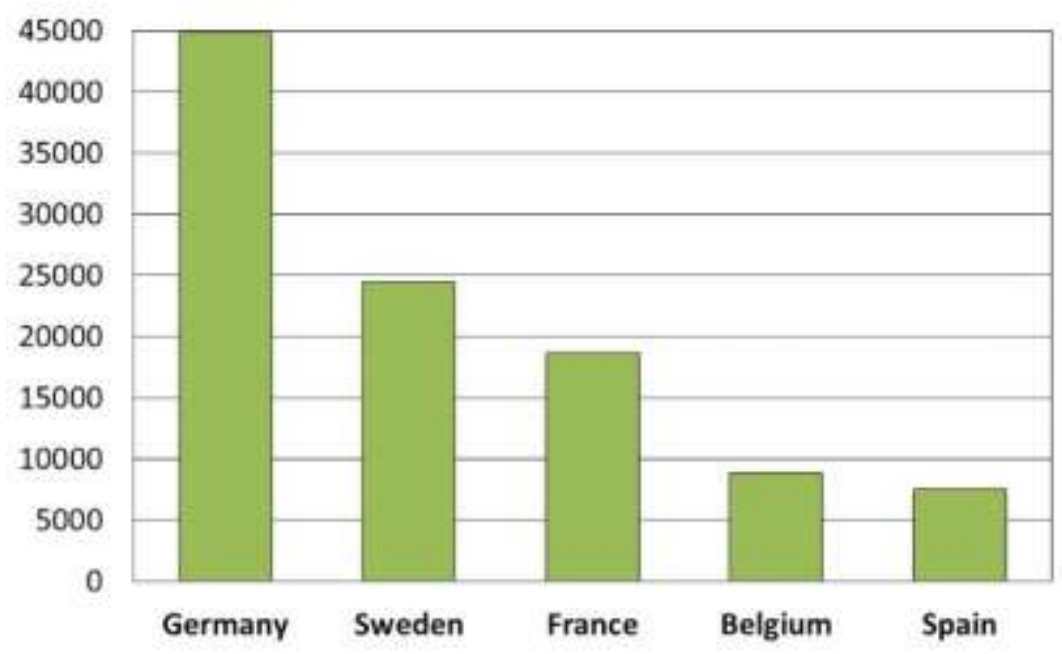

Fig. 6 European countries with the highest number of newly registered plug-in hybrid passenger vehicles in 2019. Source: [14]

The number of newly registered LPG and CNG passenger vehicles fluctuated over the years/within the monitored period (Fig.7); therefore, it is difficult to predict the general trend of gas vehicles in the market. In 2019, the highest number of newly registered LPG and CNG passenger vehicles was recorded in Italy, reaching the number of 135,366 vehicles, which accounted for 7.6\% of all new registrations of passenger vehicles. The number of newly registered CNG passenger vehicles CNG was 38,593, which accounted for $2.2 \%$ of newly registered passenger vehicles.

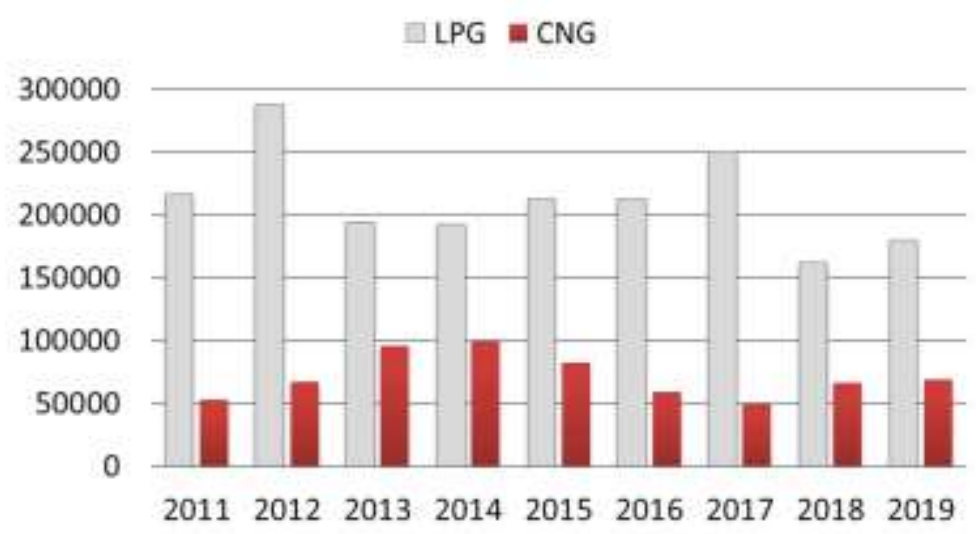

Fig. 7 Newly registered LPG and CNG passenger vehicles. Source: [14] 


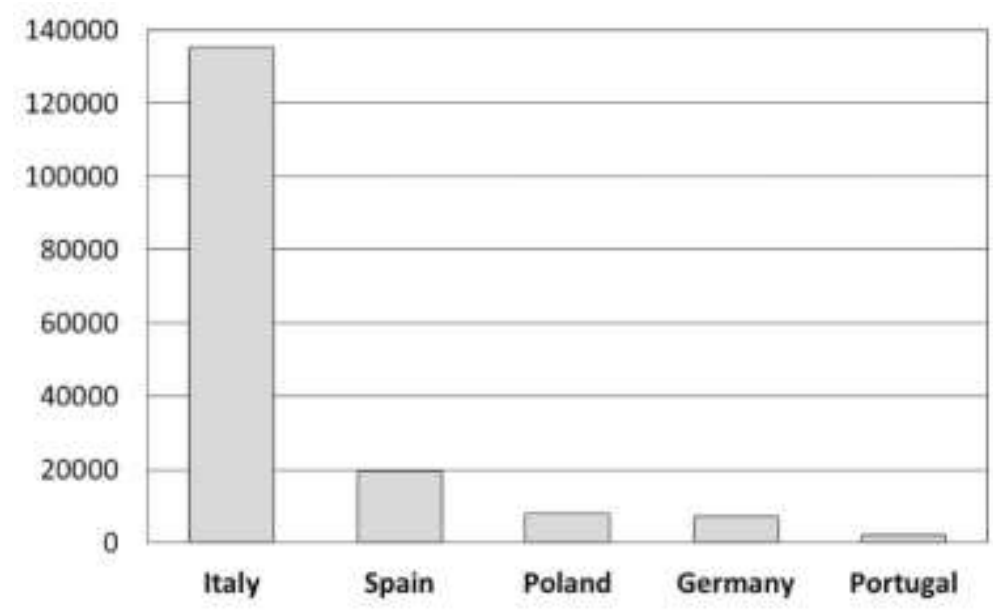

Fig. 8 European countries with the highest number of newly registered LPG passenger vehicles in 2019. Source: [14]

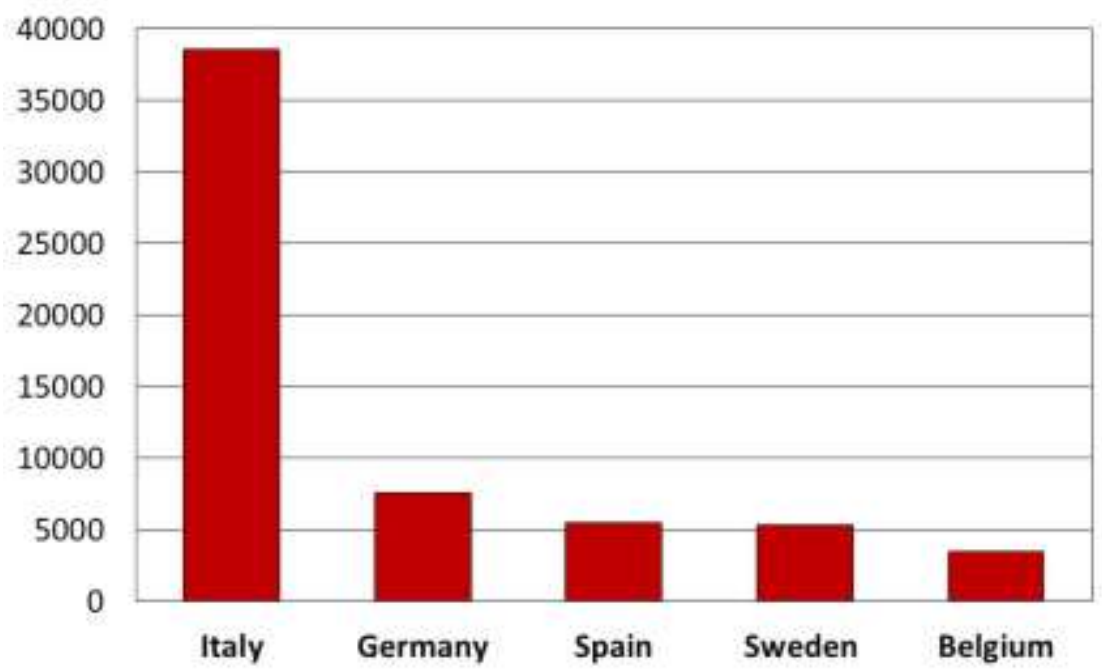

Fig. 9 European countries with the highest number of newly registered LPG passenger vehicles in 2019. Source: [14]

The number of hydrogen vehicles is still relatively low compared to others alternative fuels, but with a clear year-on-year increase. In 2019, the number of hydrogen passenger vehicles was more than 2.5 times higher than in 2018 (Fig.10). The EU countries with the highest number of newly registered hydrogen passenger vehicles included Germany, the Netherlands, France, Austria, and Italy. However, the share of hydrogen vehicles in the total number of all newly registered passenger vehicles in those countries is less than $1 \%$. 


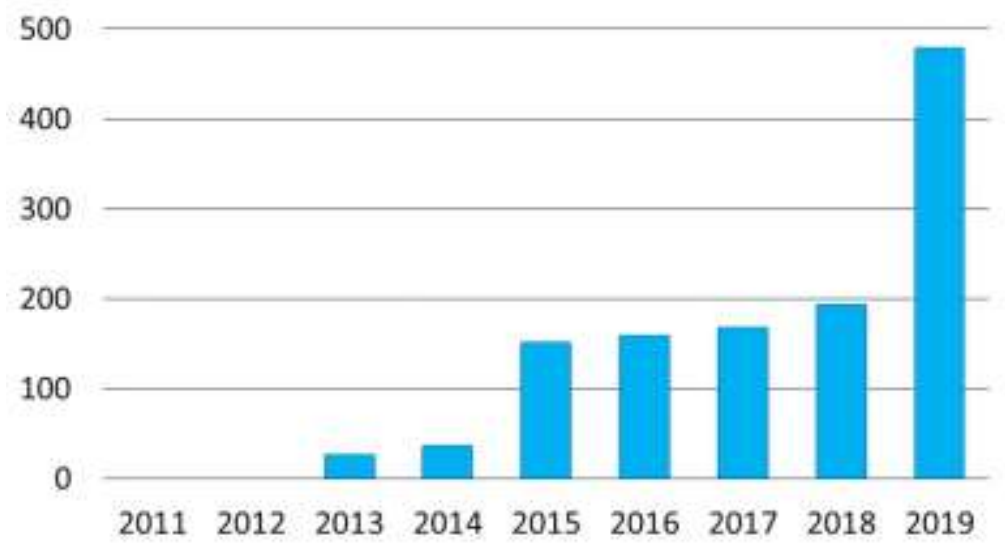

Fig. 10 Newly registered hydrogen passenger vehicles. Source: [14]

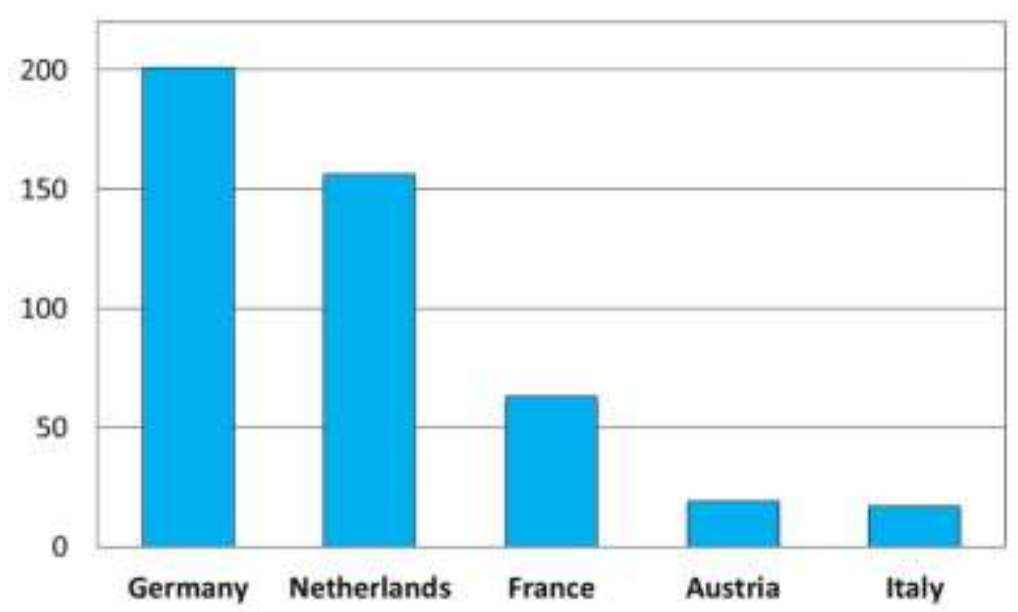

Fig. 11 Newly registered hydrogen passenger vehicles. Source: [14]

\section{Alternative Fuel Passenger Vehicles in Poland}

In 2019, the total number of passenger vehicles in Poland was $18,302,400$. The average age of a passenger vehicle was over 13 years. Passenger vehicles under four years accounted for $12.6 \%$ of all passenger vehicles in 2019 (Fig. 12). The share of passenger vehicles aged 5 - 10 years was 16.7 $\%$, while passenger vehicles aged 11 - 20 years accounted for $52.7 \%$ of the total passenger vehicles in Poland. Vehicles older than 20 years accounted for $17.9 \%$ of the number of all passenger vehicles [14-16]. 


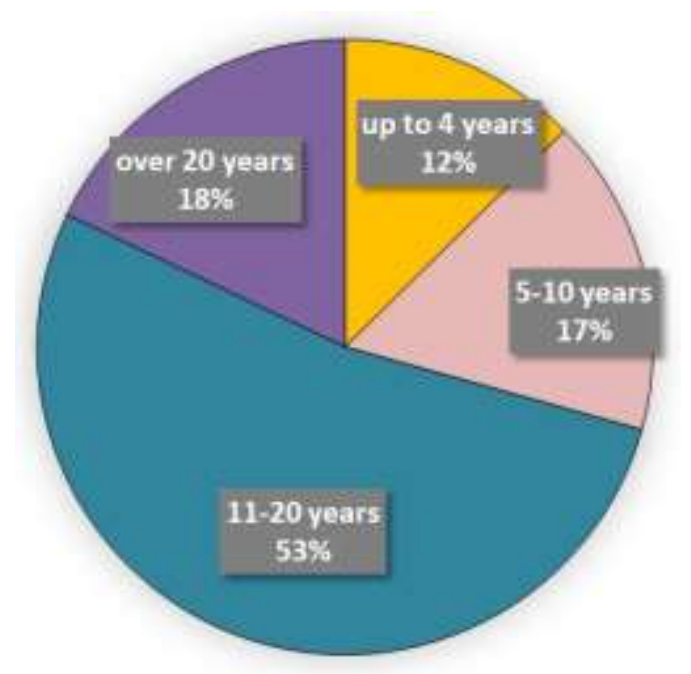

Fig. 12 Age structure of passenger vehicles in 2019. Source: [15, 17]

Figure 13 shows the type of fuel of passenger vehicles in 2019 in Poland. In 2019, almost $45 \%$ of all passenger vehicles ran on gasoline, while diesel vehicles accounted for approximately $40 \%$ of all passenger vehicles. LPG and CNG passenger vehicles accounted for almost $15 \%$. Electric and hybrid passenger vehicles represented a relatively small share in the total number of passenger vehicles (less than $1 \%$ ).

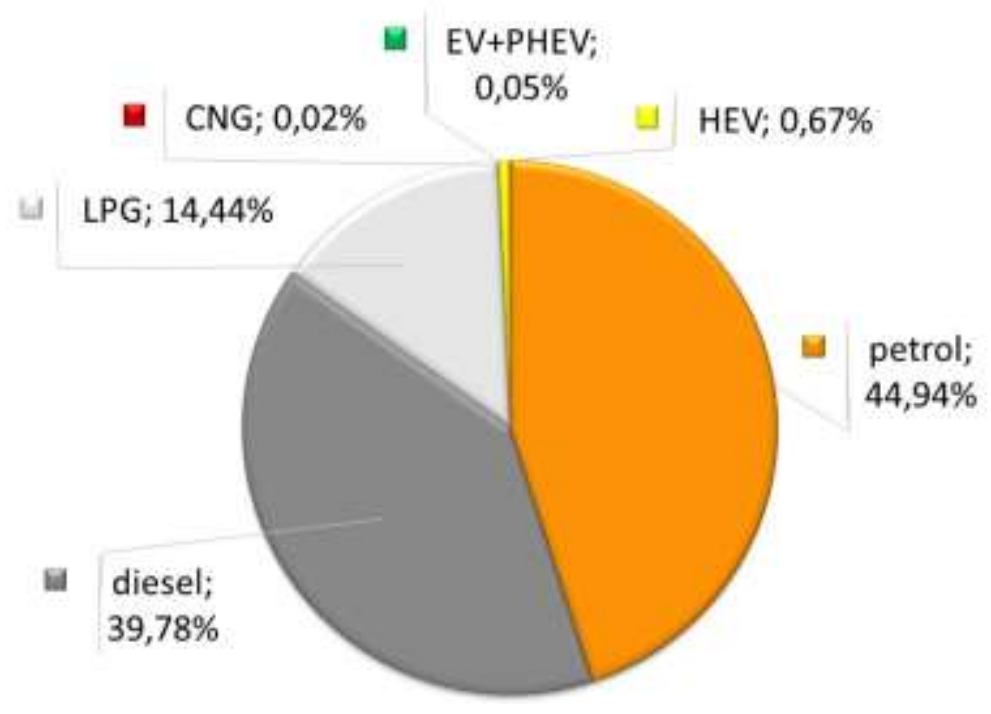

Fig. 13 Passenger vehicles by type of fuel in 2019. Source: [15]

For several years, the vast majority of alternative fuel vehicles in Poland ran on LPG (see Fig. 14). In the period of 2010-2012, LPG vehicles accounted for over a half of newly registered passenger vehicles, while in the years 2013-2017, this share was between $21.5 \%$ and $25.1 \%$. However, in the last two years, LPG passenger vehicles accounted for less than $2 \%$ of the total number of newly registered passenger vehicles in Poland. 


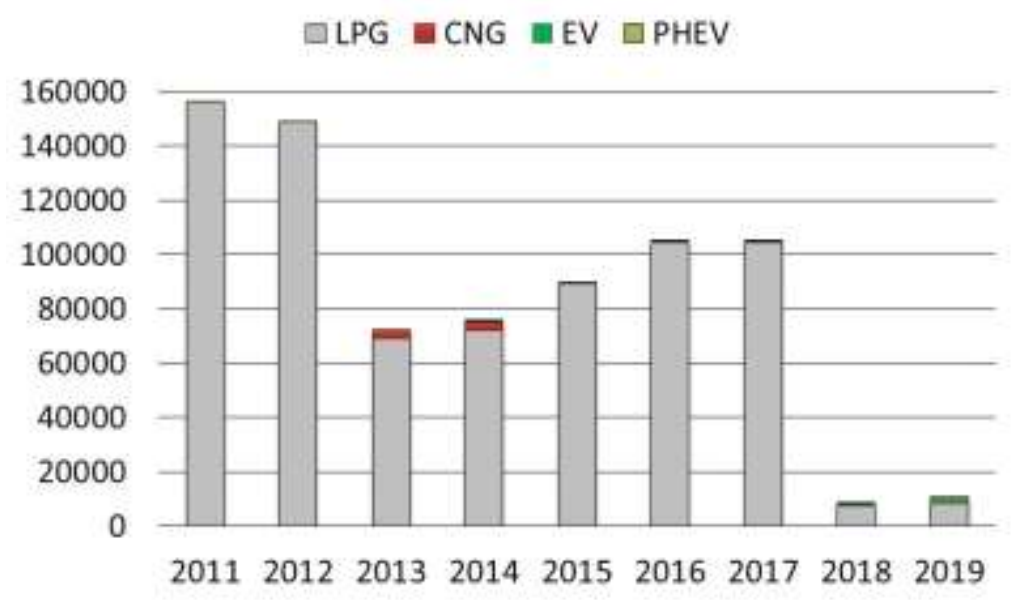

Fig. 14 Newly registered alternative fuel passenger vehicles. Source: [14]

Recently, there has been an increase in the number of electric and hybrid vehicles in Poland. Newly registered electric vehicles included 1,446 electric vehicles and 1,184 plug-in hybrids. The number of electric and PHEV passenger vehicles was two times higher in 2019 than in 2018.

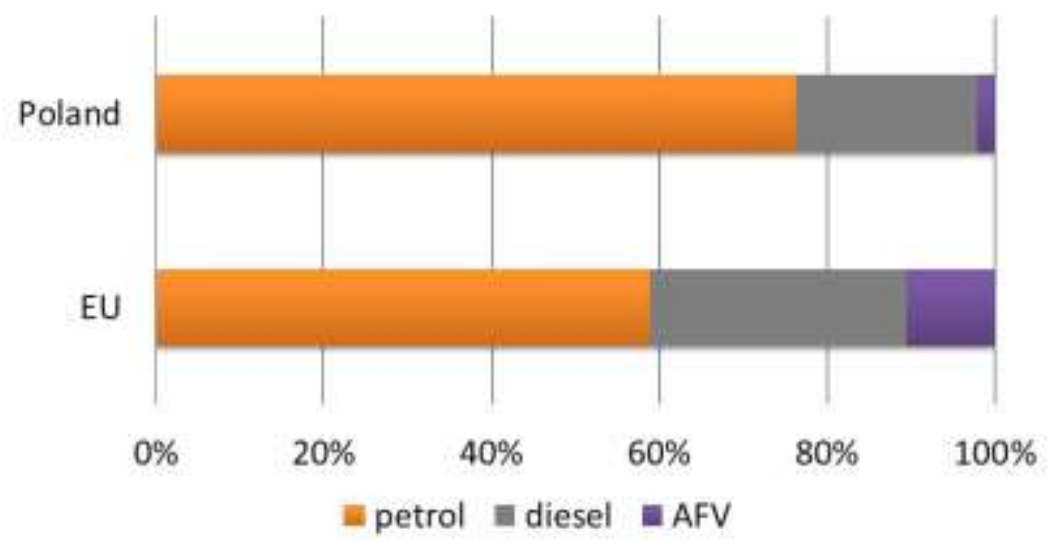

Fig. 15 Newly registered passenger vehicles by type of fuel in 2019. Source: $[15,16]$

In 2019, the vast majority of newly registered passenger vehicles ran on gasoline or diesel. Compared to the EU, Poland showed the highest share of newly registered petrol passenger vehicles. In 2019, alternative fuel passenger vehicles accounted for approximately $2 \%$ of newly registered passenger vehicles, while the number of newly registered AFV in the European Union accounted for $11 \%$ [14-16].

\section{Conclusion}

The transport sector is a major contributor to greenhouse gas emissions and pollution. In order to reduce emission of harmful substances, many countries have introduced fuel economy regulations and started to apply fiscal policy to increase the number of alternative fuel vehicles. Currently, governments of many countries all over the world have offered incentives and subsidy programs to the users of low-emission vehicles. The number of alternative fuel passenger vehicles shows a yearon-year increase. However, low emission passenger vehicles still constitute a margin share of all 
newly registered passenger vehicles in many countries. One of the major obstacles is the relatively high acquisition cost of alternative fuel vehicle compared to conventional vehicles.

\section{References:}

[1] Stańczyk, T.L. \& Hyb, L. (2019). Technological and organisational challenges for e-mobility. The Archives of Automotive Engineering - Archiwum Motoryzacji, 84(2), 57-70. DOI: 10.14669/AM.VOL84.ART5.

[2] Lewicki, W. (2017). The case study of the impact of the costs of operational repairs of cars on the development of electromobility in Poland. The Archives of Automotive Engineering Archiwum Motoryzacji, 78(4). DOI: 10.14669/AM.VOL78.ART8.

[3] Kieracińska, A. \& Hajduga, A. (2017). The use of variable-speed mechanical transmission in electric drives. The Archives of Automotive Engineering - Archiwum Motoryzacji, 75(1). DOI: 10.14669/AM.VOL75.ART3.

[4] Synák, F., Gaňa, J., Rievaj, V. \& Mokričková, L. (2019). Ways of reducing carbon dioxide from road transport. The Archives of Automotive Engineering - Archiwum Motoryzacji, 86(4), 41-54. DOI: 10.14669/AM.VOL86.ART3.

[5] Šarkan, B., Gnap, J. \& Kiktová, M. (2019). The importance of hybrid vehicles in urban traffic in terms of environmental impact. The Archives of Automotive Engineering - Archiwum Motoryzacji, 85(3), 115-122. DOI: 10.14669/AM.VOL85.ART8.

[6] Wiśniowski, P.K., Slezak, M. \& Niewczas, A. (2019). Simulation of road traffic conditions on a chassis dynamometer. The Archives of Automotive Engineering - Archiwum Motoryzacji, 84(2), 171-178. DOI: 10.14669/AM.VOL84.ART12.

[7] Qiu Q., Zhao Y., Chen L. \& Quan Y. (2012). Utilization of Urban Form Information for Extracting Commuting Travel Carbon Emission on Urban Road Network, 2012 Ninth International Conference on Information Technology - New Generations, Las Vegas, NV, 2012, (pp. 895-895). DOI: 10.1109/ITNG.2012.88.

[8] Lingsheng W., Dayong Z. \& Chen J. (2011). Strategies to reduce carbon emissions of urban passenger transport, 2011 Second International Conference on Mechanic Automation and Control Engineering, Hohhot, 2011, (pp. 6837-6840). DOI: 10.1109/MACE.2011.5988618.

[9] Ning X., Zhang J., Lu F., Qin Y. \& Yang S. (2013). Measurement the low-carbon level of residents' daily travel in Zhengzhou city, 2013 21st International Conference on Geoinformatics, Kaifeng, 2013, (pp. 1-6). DOI: 10.1109/Geoinformatics.2013.6626142. 
[10] Shanmuganathan U., Govarthanan R., Muthumailvaganan A. \& Imayakumar A. (2006) Modeling and Dynamic Simulation of IC Engine Driven Permanent Magnet Generator Using Matlab/Simulink for Hybrid Tracked Vehicle, 2006 IEEE Conference on Electric and Hybrid Vehicles, Pune, 2006 (pp. 1-6). DOI: 10.1109/ICEHV.2006.352289.

[11] Sreedhar V. (2006) Plug-In Hybrid Electric Vehicles with Full Performance, 2006 IEEE Conference on Electric and Hybrid Vehicles, Pune, 2006, (pp. 1-2), DOI: 10.1109/ICEHV.2006.352291.

[12] Yaich M., Hachicha M.R. \& Ghariani M. (2015). Modeling and simulation of electric and hybrid vehicles for recreational vehicle, 2015 16th International Conference on Sciences and Techniques of Automatic Control and Computer Engineering (STA), Monastir, 2015 (pp. 181-187). DOI: 10.1109/STA.2015.7505098.

[13] European Automobile Manufacturers Association. Alternative fuel vehicle registrations. Retrieved on October, 8, 2020, from https://www.acea.be/statistics/tag/category/electric-andalternative-vehicle-registrations.

[14] European Alternative Fuels Observatory (2020). Alternative fuel market share new registrations. Retrieved on October, 8, 2020, from https://www.eafo.eu/vehicles-and-fleet/m1.

[15] Eurostat (2020). Retrieved on October, 8, 2020, from https://appsso.eurostat.ec.europa.eu/nui/show.do?dataset=road_eqs_carage\&lang=en.

[16] PZPM (2020). Automotive Industry Report. Retrieved on October, 8, 2020, from https://www.pzpm.org.pl/en/Publications/Reports/PZPM-Automotive-Industry-Report-20202021.

[17] Green Car Congress (2020). EU diesel demand continues to drop while gasoline gains; plugins up $80.5 \%$. Retrieved on October, 8, 2020, from https://www.greencarcongress.com/2020/02/20200209-acea.html.

[18] Szumska, E., Pawełczyk, M. \& Pistek, V. (2019). Evaluation of the Life Cycle Costs for urban buses equipped with conventional and hybrid drive trains. The Archives of Automotive Engineering - Archiwum Motoryzacji, 83(1), 73-86. DOI: 10.14669/AM.VOL83.ART5.

[19] Sendek-Matysiak E. (2020) Analysis of the electromobility performance in Poland and proposed incentives for its development. Retrieved on October, 8, 2020, from https://ieeexplore.ieee.org/document/8373338/metrics\#metrics, 2018. 